\title{
Quantification of larval food and its pollen content in the diet of stingless bees - subsidies for toxicity bioassays studies
}

\author{
Rosa, AS. ${ }^{a *}$, Fernandes, MZ. ${ }^{b}$, Ferreira, DL. ${ }^{b}$, Blochtein, B. ${ }^{b}$, \\ Pires, CSS. ${ }^{c}$ and Imperatriz-Fonseca, VL. ${ }^{a}$
}

\begin{abstract}
aLaboratório de Entomologia, Programa de Pós-graduação em Entomologia, Departamento de Biologia, Universidade de São Paulo - USP, Av. Bandeirantes, 3900, CEP 14040-901, Ribeirão Preto, SP, Brazil

'Laboratório de Entomologia, Ecologia de Abelhas, Programa de Pós-graduação em Zoologia, Departamento de Biociências, Pontifícia Universidade Católica do Rio Grande do Sul - PUCRS, Av. Ipiranga, 6681, CEP 90619-900, Porto Alegre, RS, Brazil

'Laboratório de Ecologia e Biossegurança, Embrapa Recursos Genéticos e Biotecnologia, Empresa Brasileira de Pesquisa Agropecuária - Embrapa, Parque Estação Biológica PqEB, Avenida W3 Norte, CEP 70849-970, Brasília, DF, Brazil

*e-mail: annesouzar@gmail.com
\end{abstract}

Received: October 28, 2014 - Accepted: February 3, 2015 - Distributed: August 31, 2015

The pollen collected in the field by stingless bee forager workers is later processed by nurse bees, and is ultimately destined for offspring, composing the larval food. Larval nutrition in stingless bees consists of the en masse deposition of food by nurse bees and thus, all food to be consumed by a larva is deposited in the brood cell (Hartfelder and Engels, 1989). Thus, to assess the risk of pollen from crops that use pesticides and from GM crops on bee development, it is relevant to quantify the pollen consumed during the larval stage (Blacquière et al., 2012; Lima et al., 2013).

We selected the following four species of South American stingless bees that form colonies with large populations and are easy to handle: Plebeia droryana Friese, 1900; Melipona obscurior Moure, 1971; Scaptotrigona bipunctata Lepeletier, 1836, and Tetragonisca fiebrigi Schwarz, 1938. In order to provide subsidies and thus, to facilitate toxicity bioassays studies to stingless bees, we aimed to quantify the total larval food and its pollen content per brood cell in the four species.

We used three colonies of the species $P$. droryana, M. obscurior, S. bipunctata, and T. fiebrigi kept in hives in the apiary of the Pontifícia Universidade Católica do Rio Grande do Sul, Brazil. To measure both larval food and its pollen content, we collected food stored in 20 randomly selected brood cells per colony. Larval food was collected individually from each cell using $40-\mu 1$ microcapillaries. Each microcapillary was weighed on an analytical balance before and after the food collection to calculate the total food content weight/brood cell. The samples were then transferred to Eppendorf tubes containing $1 \mathrm{ml}$ of distilled water, homogenised, and filtered using a filter holder with a cellulose acetate membrane filter (Sartorius Biolab Products, pore size: $0.45 \mu \mathrm{m}$ ) where the pollen was retained. The membranes with pollen were dried in an oven at $60^{\circ} \mathrm{C}$ until complete dehydration to determine its dry mass (Lima et al., 2013), and were weighed on the same analytical balance.

Table 1 reports the total amount of larval food and pollen (both in milligrams) per brood cell for each species.

This study provided the total amount of the food and pollen to be consumed by larvae, in four species of stingless bees. The information presented herein may be combined with studies that measure the concentration of toxic substances in agricultural crops, derived both from insecticides in pollen (Blacquière et al. 2012) and from proteins expressed in the pollen of GM crops (Kim et al. 2013). When associated with such studies, the quantification of pollen obtained for the four species examined in the present study allows for estimating the amount of toxin ingested by stingless bee larva, as evidenced by Lima et al. (2013), through in vitro bioassays, using Cry1 Ac Bt-toxin. Regarding to pesticides, residues may be found both in nectar and pollen (Blacquière et al., 2012). But, for stingless bees, the importance of the quantification of pollen in larval food must be highlighted, since the highest consumption of this resource by these bees occurs during the larval stage (Zerbo et al., 2001).

In addition, as each stingless bee larva ingests the entire quantity of food provided, it is possible to know the full dose of ingested toxin (Tomé et al., 2012). In this context, this study provides a foundation for future experiments of stingless bee exposure to potentially toxic substances through the larval food. Furthermore, in vitro bioassays with stingless bees, for instance, require previously the amount of larval food to be placed on ELISA plates, as evidenced by Tomé et al. (2012) and Lima et al. (2013). Thus, besides the information of pollen quantifying, the results of the total food content consumed by larvae provided herein, may be used as subsidies for these types of bioassays in stingless bees. 
Table 1. Amount of larval food per cell and its pollen content, in different species of stingless bees.

\begin{tabular}{ccc}
\hline Bees species & $\begin{array}{c}\text { Amount of larval food per cell } \\
(\mathbf{m g})(\text { Mean } \pm \text { SE) }\end{array}$ & $\begin{array}{c}\text { Weight of pollen per cell } \\
\text { (mg)(Mean } \pm \text { SE) }\end{array}$ \\
\hline Plebeia droryana & $9.4 \pm 0.0001$ & $1.3 \pm 0.0000$ \\
Melipona obscurior & $49.8 \pm 0.0010$ & $6.0 \pm 0.0003$ \\
Scaptotrigona bipunctata & $37.3 \pm 0.0006$ & $1.9 \pm 0.0001$ \\
Tetragonisca fiebrigi & $10.1 \pm 0.0002$ & $0.4 \pm 0.0000$ \\
\hline
\end{tabular}

\section{References}

BLACQUIÈRE, T., SMAGGHE, G., VAN GESTEL, CAM. and MOMMAERTS, V., 2012. Neonicotinoids in bees: a review on concentrations, side-effects and risk assessment. Ecotoxicology, vol. 21, no. 4, p. 973-992. http://dx.doi.org/10.1007/s10646-0120863-x. PMid:22350105.

HARTFELDER, K. and ENGELS, W., 1989. The composition of larval food in stingless bees: evaluating nutritional balance by chemosystematic methods. Insectes Sociaux, vol. 36, no. 1, p. 1-14. http://dx.doi.org/10.1007/BF02225876.

KIM, HJ., LEE, SM., KIM, JK., SHIN, KS., YEO, SO. and CHO, HS., 2013. Quantification of mCry1Ac1 and PAT proteins during growth of genetically modified rice developed in Korea. Food Science and Biotechnology, vol. 22, no. 1, p. 195-200. http:// dx.doi.org/10.1007/s10068-013-0027-7.
LIMA, MAP., PIRES, CSS., GUEDES, RNC. and CAMPOS, LAO., 2013. Lack of lethal and sublethal effects of Cry1 Ac Bt-toxin on larvae of the stingless bee Trigona spinipes. Apidologie, vol. 44, no. 1, p. 21-28. http://dx.doi.org/10.1007/s13592-012-0151-z.

TOMÉ, HVV., MARTINS, GF., LIMA, MAP., CAMPOS, LAO., and GUEDES, RNC., 2012. Imidacloprid-induced impairment of mushroom bodies and behavior of the native stingless bee Melipona quadrifasciata anthidioides. PLoS One. http://dx.doi. org/10.1371/journal.pone.0038406.

ZERBO, AC., SILVA, MRLM. and BROCHETTO-BRAGA, MR., 2001. Protein requirements in larvae and adults of Scaptotrigona postica (Hymenoptera: Apidae, Meliponinae): midgut proteolytic activity and pollen digestion. Comparative Biochemistry and Physiology Part B: Biochemistry and Molecular Biology, vol. 129, no. 1, p. 139-147. http://dx.doi.org/10.1016/S10964959(01)00324-4. PMid:11337257. 